\title{
Redeployment and Rotation of U.S. Army Units in Europe
}

\author{
by \\ Lieutenant Colonel Riley J. Cheramie \\ United States Army
}

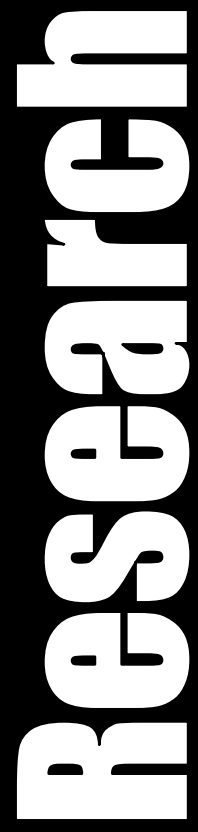

\author{
United States Army War College \\ Class of 2013
}

\author{
DISTRIBUTION STATEMENT: A \\ Approved for Public Release \\ Distribution is Unlimited
}

This manuscript is submitted in partial fulfillment of the requirements of the Master of Strategic Studies Degree. The views expressed in this student academic research paper are those of the author and do not reflect the official policy or position of the Department of the Army, Department of Defense, or the U.S. Government. 
The U.S. Army War College is accredited by the Commission on Higher Education of the Middle States Association of Colleges and Schools, 3624 Market Street, Philadelphia, PA 19104, (215) 662-5606. The Commission on Higher Education is an institutional accrediting agency recognized by the U.S. Secretary of Education and the Council for Higher Education Accreditation. 


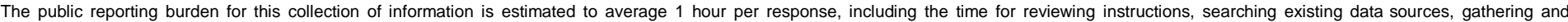

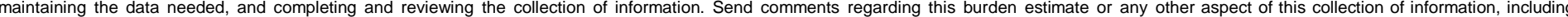

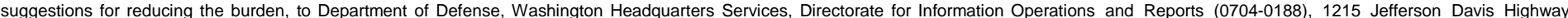

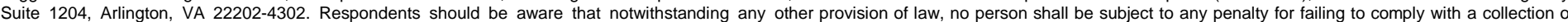
information if it does not display a currently valid OMB control number. PLEASE DO NOT RETURN YOUR FORM TO THE ABOVE ADDRESS.
1. REPORT DATE (DD-MM-YYYY)
2. REPORT TYPE
$X X-03-2013$
STRATEGY RESEARCH PROJECT

4. TITLE AND SUBTITLE

Redeployment and Rotation of U.S. Army Units in Europe

3. DATES COVERED (From - To)

5a. CONTRACT NUMBER

5b. GRANT NUMBER

5c. PROGRAM ELEMENT NUMBER

6. AUTHOR(S)

Lieutenant Colonel Riley J. Cheramie

United States Army

5d. PROJECT NUMBER

5e. TASK NUMBER

5f. WORK UNIT NUMBER

7. PERFORMING ORGANIZATION NAME(S) AND ADDRESS(ES)

Mr. Scott T. Forster

8. PERFORMING ORGANIZATION REPORT NUMBER

Center for Strategic Leadership and Development

9. SPONSORING/MONITORING AGENCY NAME(S) AND ADDRESS(ES)

U.S. Army War College

122 Forbes Avenue

Carlisle, PA 17013

10. SPONSOR/MONITOR'S ACRONYM(S)

11. SPONSOR/MONITOR'S REPORT NUMBER(S)

12. DISTRIBUTION / AVAILABILITY STATEMENT

Distribution A: Approved for Public Release. Distribution is Unlimited.

13. SUPPLEMENTARY NOTES

Word Count: 5,163

\section{ABSTRACT}

The U.S. Army plans to reduce warfighting capability forward deployed in Europe. This reduction of forces comes following ten years of war, prolonged U.S. economic recession, and a pivot towards the Asian Pacific region. The Army will redeploy two brigade combat teams (BCT), begin operational deployments of a combat battalion, and regionally align CONUS units to Europe. Europe may be confronted by traditional threats and emerging threats of failing states in the region. The new military posture in Europe will confront these threats by focusing on building partnership capacity with European and Coalition partners through security cooperation and theater engagement activities to prevent conflict and shape the environment. The U.S. partners and allies must equally contribute forces to the security in the region. The Joint Multinational Training Command (JMTC) in Germany will be the centerpiece for U.S. Army bilateral and multilateral training, Coalition partner integration and interoperability training, and force projection. The new military posture will continue to assure U.S. allies of our commitment and demonstrate to potential regional adversaries the U.S. military readiness, flexibility, agility, and reach.

\section{SUBJECT TERMS}

Partnership, Multinational, Force Projection, Joint Multinational Training Command, Regionally Aligned Forces

16. SECURITY CLASSIFICATION OF:

a. REPORT

UU

b. ABSTRACT

UU
17. LIMITATION OF ABSTRACT

UU
18. NUMBER OF PAGES

30 19a. NAME OF RESPONSIBLE PERSON

19b. TELEPHONE NUMBER (Include area code) 

USAWC STRATEGY RESEARCH PROJECT

\title{
Redeployment and Rotation of U.S. Army Units in Europe
}

\author{
by \\ Lieutenant Colonel Riley J. Cheramie \\ United States Army
}

\author{
Mr. Scott T. Forster \\ Center for Strategic Leadership and Development \\ Project Adviser
}

This manuscript is submitted in partial fulfillment of the requirements of the Master of Strategic Studies Degree. The U.S. Army War College is accredited by the Commission on Higher Education of the Middle States Association of Colleges and Schools, 3624 Market Street, Philadelphia, PA 19104, (215) 662-5606. The Commission on Higher Education is an institutional accrediting agency recognized by the U.S. Secretary of Education and the Council for Higher Education Accreditation.

The views expressed in this student academic research paper are those of the author and do not reflect the official policy or position of the Department of the Army, Department of Defense, or the U.S. Government. 



\begin{tabular}{ll} 
& \multicolumn{1}{c}{ Abstract } \\
Title: & Redeployment and Rotation of U.S. Army Units in Europe \\
Report Date: & March 2013 \\
Page Count: & 30 \\
Word Count: & 5,163 \\
Key Terms: & Partnership, Multinational, Force Projection, Joint Multinational \\
& Training Command, Regionally Aligned Forces \\
Classification: & Unclassified
\end{tabular}

The U.S. Army plans to reduce warfighting capability forward deployed in Europe. This reduction of forces comes following ten years of war, prolonged U.S. economic recession, and a pivot towards the Asian Pacific region. The Army will redeploy two brigade combat teams $(\mathrm{BCT})$, begin operational deployments of a combat battalion, and regionally align CONUS units to Europe. Europe may be confronted by traditional threats and emerging threats of failing states in the region. The new military posture in Europe will confront these threats by focusing on building partnership capacity with European and Coalition partners through security cooperation and theater engagement activities to prevent conflict and shape the environment. The U.S. partners and allies must equally contribute forces to the security in the region. The Joint Multinational Training Command (JMTC) in Germany will be the centerpiece for U.S. Army bilateral and multilateral training, Coalition partner integration and interoperability training, and force projection. The new military posture will continue to assure U.S. allies of our commitment and demonstrate to potential regional adversaries the U.S. military readiness, flexibility, agility, and reach. 



\section{Redeployment and Rotation of U.S. Army Units in Europe}

The U.S. Army plans to reduce its force structure and warfighting capability in the European theater as part of a Department of Defense (DOD) military strategy to rebalance military capability toward the Pacific theater ${ }^{1}$. To do this, the Army developed a plan and will realign forces according to the new priorities outlined by Department of Defense Secretary Panetta. ${ }^{2}$ The realignment of forces in Europe comes at a time when the U.S. government is concerned about the emerging economic and military power of China. Although the Department of Defense's focuses more toward the Pacific theater and less to the European theater, it should not completely abandon the U.S. longtime allies, partners, and friends in Europe in the future. The U.S. should maintain a credible force and force projection infrastructure capacity in Europe to ensure peace and prosperity in the region. As U.S. forces draw down in Europe it will be imperative to build greater partner capacity and increase military integration and interoperability with North Atlantic Treaty Organization (NATO) nations and other European allies.

At the same time the U.S. plans to rebalance toward the Pacific theater, the U.S. is struggling with a budget crisis brought on by an economic recession since 2008 , which directly impacts the plans for rebalancing toward the Pacific theater. The U.S. Congress will need to make tough choices on priorities of funding in the budget. The Department of Defense understands the economic challenges the U.S. government is currently facing. In fact, the former Chairman of the Joint Chiefs of Staff, General Meyers, stated that the budget is the number one national security threat to the U.S .

Since 2003, the Department of Defense has focused attention on the ground wars in Afghanistan and Iraq. These costly wars have contributed to an already growing U.S. debt and economic crisis. The Department of Defense budget has grown 
to over $\$ 525$ billion. ${ }^{4}$ Although the cost of war and maintaining a large military force is becoming increasingly expensive, the U.S. Army over the course of ten years of war has drastically improved its warfighting capability in weapons systems, soldier readiness, intelligence and technology. Technology of equipment and systems in the Army has greatly improved the effectiveness and warfighting capability to the point that the Army may be capable of achieving greater military capability with less force structure, hence it is possible for the Army to decrease in size but still remain a powerful force. Procurement of technology and personnel costs has become increasingly expensive. As stated by the Chairman of the Joint Chiefs of Staff, the Department of Defense must begin to tradeoff fewer resources for more innovation. ${ }^{5}$ The Department of Defense believes it can take risks in reducing total procurement and personnel while maintaining its world-wide military capability. The Army must get smaller but retain capability. The U.S. Army reduction of forces in Europe is the initial actions to reduce total force population and force structure.

In times of declining resources, the Army is also shifting its land power capability through global force realignment to array forces according to regional threats. Since there will be less forces, the Army must realign forces globally to prevent future conflict, shape the international environment, and when necessary employ the force to win decisively. ${ }^{6}$ The Army will reduce its overall forces of active duty Army over five years from 570,000 to a lower manpower force and force structure of $490,000^{7}$ and may be required to reduce funding for future procurement programs. The Army will be required to decrease forward deployed forces especially in Europe and maintain an offshore balance emphasizing more theater engagement. ${ }^{8}$ Christopher Lane describes offshore 
balancing as a strategic concept of reducing large formations of ground forces forward deployed in a region and replacing the troop capability with a combination of U.S. missiles, U.S. Navy and airpower to deter potential hostile forces. ${ }^{9}$ The Army will redeploy its large formations of forward deployed troops stationed in Europe back to the continental U.S. (CONUS). Troops redeploying from Afghanistan by the end of 2014 will also return to bases in CONUS. The Army will reduce two brigade combat teams stationed in Europe and re-station these units in the U.S. As the U.S. redeploys brigades to CONUS or inactivates units, the Army troop presence and footprint of bases in Europe will decrease. The Army will align forces stationed in CONUS to designated regions. When the Army calls upon these regionally aligned forces (RAF) to deploy, the RAF will be particularly knowledgeable of the environment in the region and this awareness will lessen preparation and training time for deployment. ${ }^{10}$

As the Army draws down in the European theater, specifically in Germany and Italy, two brigade combat teams and the $\mathrm{V}$ Corps headquarters, the remaining units will move and consolidate to facilities on forts and bases. The draw down and restructuring will reduce Army Soldier presence throughout the region, make more effective use of facilities in Europe, and drastically decrease overall costs. As units consolidate to the few military bases, the Army will shut down vacated facilities and return them to the respective European country governments. This will reduce the operating costs of the U.S. Army in the European theater. As the troop posture in Europe evolves, the U.S. will maintain its commitment to NATO. ${ }^{11}$

\section{U.S. Evolving Posture in Europe}

Due to U.S. budget challenges requiring the Army to reduce force structure and evolving strategic landscape prompting the U.S. to rebalance toward the Pacific, the 
U.S. Army posture in Europe will evolve. The largest impact will be the troop reduction. The troop reduction will have an impact on U.S. security in Europe but will also have an unknowable impact on the political, informational, and economic aspects of the U.S. presence in Europe. However, the Army must reduce its forces. To do this the Army will inactivate and redeploy two forward-deployed brigade combat teams (BCT) currently in Europe. The two BCTs identified to inactivate are the $170^{\text {th }}$ BCT scheduled for fiscal year 2013 (FY 2013) and the $172^{\text {nd }}$ BCT, scheduled for FY 2014. ${ }^{12}$ The U.S. Army, Europe (USAREUR) will reduce the V Corps headquarters and transform the $7^{\text {th }}$ Army to a deployable command post to reduce the U.S. Army force structure by approximately 2,500 Soldiers. ${ }^{13}$ USAREUR will allocate a heavy combat brigade stationed in Continental United States (CONUS) to the North Atlantic Treaty Organization (NATO) Response Force to enhance NATO capability and interoperability. A battalion sized task force from the allocated heavy brigade of the NATO Response Force will rotate through the Joint Multinational Training Center (JMTC) in Grafenwohr, Germany to conduct multinational training exercises. ${ }^{14}$

The Army will reduce the total number of forces stationed in Europe, consolidate bases and facilities and focus on partnering with allies and coalition nations in order to move to an offshore balancing strategy. With this evolution, the U.S. must maintain a credible deterrence for potential threats to Europe. The U.S. must improve the capabilities of the Joint Multinational Training Command (JMTC) to focus on partnering and multinational integration and interoperability. Also, with the reduction of forces in Europe, the U.S. must improve its force projection through operational deployments, 
exercises of Joint and Coalition reception, staging, onward movement, and integration (RSOI), and infrastructure of power projection platforms.

Lesser forces forward deployed in Europe means the U.S. and Coalition nations must be able to rapidly deploy to reinforce the forces forward deployed. Potential threats in Europe still exist. Therefore, the U.S. must increase emphasis on the JMTC as a strategic rotational training center, Coalition integration site, and a critical force projection platform to ensure deterrence in maintained in Europe.

Threats to Europe

Since World War II (WWII), the U.S. has had troops stationed in Europe. These troops played a prominent role in NATO. At the height of troop stationing, the U.S. had over 1.2 million troops in Europe. These troops ensured the security of the U.S. National interest and the security of its European allies after the war.

During the Cold War, alongside its NATO partners, the U.S. has created a credible deterrence to a hegemonic USSR. Over time, the U.S. reduced its military capability in Europe but has periodically exercised its ability to deploy large formations of forces to the region as a show of force or show of capability to deter USSR from invading Europe. Large division-level exercises called REFORGER were effective in reinforcing U.S. presence in Europe. In order to conduct these exercises, the Army retained logistic facilities and bases in Europe to quickly receive and support large military reinforcements. The exercises were an effective deterrent during the Cold War. This important concept should not be lost or forgotten as the U.S. looks to draw down the Army in Europe yet again.

History has shown that the U.S. actions in the past to retain or bolster quick military build-up through existing military capability in the region has ensured the USSR 
had not made any miscalculations about the U.S. credibility and resolve. But, as the U.S. has become effective in reducing the USSR threat, the U.S. allies in Europe have reduced military budgets commensurate of the perceived threat. The European and NATO nation's budgets have declined to a point that it has created a military capabilities gap in procurement, development, and technology between the U.S. and European allies. ${ }^{15}$ Although the USSR threat had greatly diminished after the crumbling of the USSR government and the end of the Cold War, the U.S. had concerns about the military capability of its NATO allies. Have NATO allies reduced military budgets too low to effectively assist the U.S. or respond to other NATO nations' call for assistance in the future? This was especially apparent in the 1990s when the U.S. deployed forces to the Balkans. ${ }^{16}$ Although the old threat of the USSR has diminished, new ones have quickly evolved or are evolving which the Europeans may not be capable of thwarting.

New threats to Europe are growing at the same time the U.S. has begun to rebalance or focus more military capability and emphasis toward the Pacific where a greater threat to U.S. and global interests are increasingly at stake. This rebalance toward the Pacific requires the U.S. to reduce U.S. troop capability in Europe.

As the U.S. reduces forces in Europe to a sustainable level in which the U.S. budget can efficiently support, the European and NATO nations must recognize the increasing new threats and their declining military budgets to effectively address these threats. There are telling signs that the announcement of U.S. drawdown in Europe has informally created a beacon of reflection of some European country's security posture.

Europe still remains a pillar of the U.S. defense strategy to prepare and quickly react to threats that may develop in the region. However, European militaries are 
drawing down force levels due to budgetary constraints. They are doing so independent of each other. ${ }^{17}$ The Europeans should use the U.S. concept of Base Realignment and Closure (BRAC) as a basis to consolidate and pool its resources. Pooling of resources will help the Europeans build institutional capability to assist the U.S. in preventing and deterring potential adversaries in the region and elsewhere in the world. ${ }^{18}$ If the Europeans cannot transform to a pooling system of their military capabilities, the U.S. will lose a good part of their ability to prevent threats in the region. Additionally, the U.S. will be unable to count on the Europeans for training, integration, and interoperability of militaries to conduct allied and coalition operations in the future. ${ }^{19}$ The U.S. will find it very difficult to show legitimacy to forge future wars without building a military coalition. The U.S. will have to act unilaterally to protect its national interests in Europe.

It is clear Europe, like the US, will be confronted by threats from failing states and increasing non-state actors in the region and worldwide. ${ }^{20}$ Particularly, based on the US and European security strategies, threats deriving from failed states may provide the impetus for terrorism, nuclear material proliferation, and organized crime. Some failed states may require multinational humanitarian assistance. ${ }^{21}$ The U.S. and Europeans must start now to develop an expeditionary multinational military capability it needs to quickly project its power globally.

Russia, because of its size and geopolitical reputation, is still one of the largest concerns for the U.S. in the European theater. The U.S. must continue its 'reset' efforts with Russia in order to maintain open communications with Russia. Recently, Russia has rebuked the U.S. outreach efforts because Russia believes the U.S. and the 
European Union are in decline. Vladimir Putin wants to position Russia as a $21^{\text {st }}$ Century center of power. ${ }^{22}$

There are a number of scenarios and uncertainties that can create unrest or national security issues for U.S. interests in Europe. Russia still remains a world power that possesses the ability to create problems for the US. There are a number of threats inherent with Russia and its former states: objection to U.S. missile shield, Russian flow of natural gas to Europe, nuclear material proliferation, terrorism, transnational crime, and an Arab spring-like uprising in Russia. The U.S. presence in Europe will demonstrate to Russia that the U.S. is committed to the collective defense of Europe.

The primary reason to maintain forces forward-deployed in Europe is the most dangerous one. This is the possibility of failing or failed states. The recent breakaway states of the Russian Empire in Eastern Europe are fragile. These states could possibly fail and become havens for terrorists or areas needing humanitarian assistance. The U.S. Army forces in Europe, if in proximity to these states, can quickly deploy forces or humanitarian aid to those nations. According to the failed states index of The Fund for Peace (FFP) 2012, Conflict Warning and Assessment, Georgia, Bosnia, Belarus, and Serbia, top the list for transnational threats of nuclear proliferation, terrorism, transnational crime, and other problems stemming from failed-state status. ${ }^{23}$ Joint Multinational Training Command

The U.S. must increase emphasis on the JMTC as a strategic rotational training center, Coalition integration site, and a critical force projection platform to ensure it maintains deterrence in Europe. With the reduction of the Army forces and subsequently, the installations used by units, especially in Germany, the Joint Multinational Training Command (JMTC) will be a key strategic training facility for the 
U.S. and our European partners and allies. The JMTC must be the focal point for the US presence in Europe. This facility will serve as the premier training facility for training with European forces to promote and enhance multinational integration and interoperability. ${ }^{24}$ Additionally, it must become a center for training rotational forces regionally aligned with the European theater. A regionally aligned force is a vision by the Secretary of the Army and Chief of Staff of the Army for providing combatant commanders with versatile, responsive forces to conduct operational missions and exercises in theater to support theater engagement activities. ${ }^{25}$

The JMTC is and will continue to be the facility to train the two brigade combat teams currently forward deployed in Europe. The Army's role is to provide combatant commanders with a sustained supply of trained and ready forces for unexpected contingencies. ${ }^{26}$ The JMTC will at some point produce trained and ready multinational forces for Coalition operations. As the U.S. draws down, the plan is to rotate a battalion sized unit from a regionally aligned division ${ }^{27}$ through the JMTC in a similar fashion as the National Training Center (NTC), at Fort Irwin, California. The purpose of the rotation of the battalion through JMTC will be to save money on permanently stationing those forces in Europe, expanding multinational training and partnering, and to demonstrate U.S. national interest in Europe. The capability to deploy, train, and employ a battalion combat unit effectively will serve as a deterrent to adversaries interested in taking advantage of a worldwide situation outside of Europe or to create an armed conflict within Europe. ${ }^{28}$

\section{$\underline{\text { Rotation of Battalion }}$}

With the evolving landscape and reduction of forces in Europe, the centerpiece of the U.S. Army engagement in the European theater will be the rotation of regionally 
aligned battalions through the Joint Multinational Training Command (JMTC) in Grafenwohr and Hohenfels, Germany. The rotating battalion will be able to conduct unilateral and bilateral training. Rotating a battalion through the JMTC can produce ready and trained force for the geographical combatant commander to augment the Army Forces Generation (ARFORGEN) program. Upon validation and completion of the battalion training, the Army can subsequently employ units in an area of operation in the theater to engage, support bilateral or multinational military training exercises ${ }^{29}$, or easily deployed to an adjacent theater in the Middle East or the African continent.

Likewise, the JMTC can prepare regionally aligned units to quickly integrate with multinational Coalition units and operate effectively in the region. These units will increase their language proficiency, cultural awareness, communication, logistics, doctrine understanding, and better understand their theater environment. The geographical location of the JMTC better positions Army forces to train and integrate with Coalition forces then deploy to a strategic crisis event, all while supporting security assistance and theater engagement activities in Europe. ${ }^{30}$

\section{Partnering}

The future size and capability of the U.S. military will require it to become innovative in the way it approaches future threats in the European theater. The wars between nations or large formations of troops in Europe are not likely to occur in the future. The U.S. will likely face adversaries of the asymmetrical type. These are adversaries that engage in terrorist activities, organized crime, or proliferation of nuclear weapons. The U.S. must assess these future threats as the theater draws down forces in Europe. The U.S. must use all resources available to implement a military strategy and force for the future. Since the end of World War II (WWII), European nations have 
largely relied on the U.S. to provide security around the world that allowed nations to trade freely and provide the necessary freedom to prosper. The export of security came at a price that the U.S. can no longer afford. ${ }^{31}$ Meanwhile, European nations have invested less in their own militaries. Now, in a time of austerity of budget constraints, both the US and Europe will need to work together to expand strategic and operational partnership as they each adapt to emerging realities in providing regional security. ${ }^{32}$ The U.S. will have to rely on its European partners and allies to share the burden of global security. ${ }^{33}$

The U.S. Army must retain some credible capability that is affordable but fully capable to prevent nations or non-state actors from initiating hostilities that can result in costly wars. The force in Europe should be agile, tailor-able, and versatile. It must be an expeditionary force. It must be able to shape the environment of its likely adversaries. ${ }^{34}$ But, the U.S. can no longer fulfill this role independently. The only way the U.S. can reduce its forces in Europe and still maintain the same level of security is to forge full partnerships with European nations. The U.S. Army must enable European allies through 'mil-to-mil' exercises, training in doctrine and procedures, and share equipment. The U.S. has always confronted adversaries united with its European partners, but the U.S. has always provided the preponderance of the capable force. The U.S. can no longer achieve the same results with a smaller force. The U.S. will be reliant on the European nation partnerships to shape the future environment and prevent future hostilities. This notion is no longer a secondary thought. Training, advising, and partnering with foreign forces has become a critical skill set. ${ }^{35}$ In order to have true partnerships that each can rely on the other, there must be trust. The 
European and other allies' militaries must be able to integrate and have interoperability with U.S. doctrine, training, and equipment. This success can only be possible through extensive training and exercise. Theater security cooperation with European nations builds operational capacity and capability while also achieving U.S. strategic objectives. Theater cooperation activities increase multinational interoperability and support U.S. military capabilities. Together the U.S. and its partners can set the conditions to deter potential adversaries. ${ }^{36}$ Through security cooperation assistance, the U.S. must be capable in partnering with other nations ${ }^{37}$ and quickly expanding its own capability with augmentation from CONUS as required.

An advantage to partnering with European nations is that it is less costly to share the burden. Each nation would provide a percentage of their military to a given cause. Partnering with other nations would also make it easier to respond to a natural catastrophe or a humanitarian crisis in that particular country. Partnering will make training and access to the country or region much easier for the U.S. Units of the U.S. military would learn beforehand the language and culture of the country before deploying forces for a military, natural, or humanitarian event. Partnering with other nations would allow U.S. Army forces to exercise military capability, but also apply elements of national power. The Army will align a division with the European theater as the unit to train, partner, and assist with national security cooperation for that specified region. These units would likely be the first unit to respond to any military, natural, or humanitarian event requiring U.S. action. Units forward deployed in Europe have deployed to other regions because of the proximity to the event. The U.S. forces can 
fulfill a full range of missions both unilaterally and multilaterally, as a lead nation or supporting nation, as needed.

Force Projection

The importance of military forces forward-deployed in Europe cannot be understated. Although the force is small and decreasing in size, the capability to prevent hostilities remains strong. When these forces are not sufficient to prevent hostilities, the U.S. will quickly deploy additional forces from CONUS to augment forward-deployed forces in order to gain an early decisive advantage.$^{38}$ The ability of the U.S. to project power in the region and into neighboring theaters of operations such as the Middle East and Africa will protect and maintain US national interests. ${ }^{39}$ As the U.S. draws down forces in Europe to a size that is credible and still capable to prevent and shape the environment of potential adversaries, the U.S. must maintain a capability to project its power. The Department of Defense dictionary of military and associated terms describes force projection as, "the ability to project the military instrument of national power from the United States or another theater, in response to requirements for military operations." ${ }^{40}$

The growing challenge to U.S. superior land forces force projection is the ability of nations to prevent access to a theater of operation. The Joint Staff describes the term anti-access as actions of a nation to prevent an adversary from deploying into an area of operation. ${ }^{41}$ With the increasing availability of technology, various countries are acquiring anti-access weapons systems to prevent nation's access. Many nations recognize the superior force of the U.S. and prefer to restrict access from entry into the geographical region. The U.S. must overcome this anti-access challenge in order to project forces when and where needed. Setting the conditions for successful access 
into a region like Europe is a very important goal. The Army, forward-deployed at bases in Europe, along with the Joint Force must continuously shape the region through theater engagement and security cooperation activities. In order to establish favorable conditions for access within a region, military activities such as multinational exercises, integration training at the JMTC, and support agreements with European partners and allies are necessary pre-conditions to facilitate force projection. Other important preconditions that facilitate access are improvements of the JMTC as a force projection platform and increased capability of the prepositioned equipment stocks in Europe. ${ }^{42}$

Since 1952, the U.S. has had the ability to quell violence and prevent hostilities early in the chain of events that may have led to war, due to the ability to project power or deploy quickly with the right force or overwhelming force. The ability to bring forces to bear in a rapidly deteriorating situation can prevent these situations from growing into a large scale conflict or war. The U.S. has done exactly that since the end of World War II.

In 1968 the U.S. redeployed two Army divisions from Europe back to the U.S. in a deliberate force drawdown. To demonstrate to NATO the ability of the U.S. to quickly reinforce forces forward-deployed in Europe, the U.S. conducted a large scale deployment of a division equivalent size force from CONUS to Europe. This exercise was known as 'return of forces to Germany' or REFORGER. REFORGER became an annual exercise which began in 1969 and ended in 1993. The exercise grew to more than a demonstration of U.S. power and deployment capability. REFORGER was an actual plan to quickly supply U.S. forces to NATO in case of an actual war. The exercise was very successful in deterring adversaries throughout the Cold War. 
Currently as the U.S. begins to drawdown in Europe again, there are some similarities from REFORGER that are relevant today.

In order for the U.S. to quickly build forces in the theater during REFORGER, the U.S. depended on a successful concept of prepositioning supplies and equipment. Today, the Army Preposition Stock (APS) in Europe is one of five prepositioned war sets located in key strategic locations around the globe. The APS-2 in Europe contains prepositioned sets of equipment, operational project (OPRJ) stocks, ammunition, Army war reserve sustainment (AWRS) stocks, and war reserve stocks for U.S. allies (WRSA) ${ }^{43}$ The use of APS reduces the strategic air and sealift needed in the region and also greatly reducing response time for ready and capable forces. The concept of the APS also greatly reduces costs and improves the credibility of U.S. force projection in the region. The APS is a critical component to force projection. The Army must revitalize the APS-2 to maintain and tailor equipment to meet the needs of today's force structure. ${ }^{44}$

The U.S. forces forward deployed in Europe have provided military responses to crisis since the end of WWII. In 1958, Operation Blue Bat, the U.S. provided logistical support from U.S. bases in Europe to U.S. deployed forces in Lebanon. ${ }^{45}$ The U.S. also deployed forces from Europe in 1982 in support of a multinational force in Lebanon. In 1990, at the start of the first Gulf War, the U.S. deployed the bulk of the forces to U.S.

Central Command. The U.S. deployed 75,000 soldiers from Europe along with all of the units' equipment and supplies. This was possible because of the readiness of forces, capability and capacity of the European theater power projection platform (airports and seaports), and the proximity of European forces to the theater of war. ${ }^{46}$ U.S. forces 
deployed from Europe to Bosnia, Kosovo, Operation Desert Storm, Afghanistan, and Operation Iraqi Freedom. ${ }^{47}$ The US bases in Europe are strategically located for the U.S. to quickly react to hostile actions in the region. These bases are also capable of providing a jumping-off point for deployment into other nearby theaters if necessary.

As the redeployment of forces and the drawdown of service support installations and equipment in Europe continue, it is imperative the U.S. retain the capability to project power as it has done in the past with great success. The Army power projection platform can provide rapid, global deployment of forces. Army power projection platform (AP3) is the set of initiatives and strategic mobility enabling systems required to meet current and future force projection and deployment requirements." ${ }^{\text {"8 }}$ The U.S. must ensure European critical strategic transportation nodes are enhanced and retained for military force projection. Specific critical modes of airports such as Ramstein Air Force Base, seaports such as Bremerhaven, and railheads such as Baumholder and Grafenwohr, Germany and Vicenza, Italy must be maintained to not only project force to other regions but also to receive new reinforcing troops from CONUS into the European theater. These force projection platforms will ensure U.S. and Coalition forces can deploy and redeploy rapidly and effectively.

Currently, U.S. and European transportation deployment infrastructure in Germany is currently capable of providing the mobility needed to quickly respond to crisis in and outside of Europe. But, as the U.S. reduces and restructures capability in Europe, they must not overlook the power projection platforms. In fact the U.S. and Europeans must improve the platforms to deploy forces currently in Europe to the crisis and to receive forces from CONUS or other countries. As the JMTC will serve as the 
integration point for Coalition forces, JMTC must develop a modern and efficient multinational process for reception, staging, onward movement (RSO) of U.S. and coalition forces. It must also be the platform used to project the force into an area of operation.

The Coalition reception, staging, onward movement, and integration (RSOI) process at JMTC will ensure U.S. and Coalition marry-up multinational forces early in the process and maximize strategic sea and airlift assets. Rotation of the battalion to JMTC using a JRSOI process will serve as an excellent tool to train U.S. battalions as well as the multinational or coalition units on the RSOI process for actual deployment into a theater of war.

Most importantly is that the Army improves the JMTC deployment infrastructure capability to a state of the art infrastructure. When called to deploy, the two brigades forward-deployed in Europe will need to quickly rotate through JMTC for validation training prior to deploying to a combat location. The same is true for a battalion rotating from CONUS and also a mixture of coalition forces from various countries. The capability for these forces to quickly deploy from the JMTC to a combat location will be critical. The Army must maintain the JMTC as a power projection platform to ensure units deploy quickly to positively impact the initial stages of a crisis.

\section{Conclusion}

The U.S. economic recession since 2008 and the fiscal crisis will cause the Department of Defense to reduce its budget. Additionally, the economic and military emergence of nations in the Pacific region requires the U.S. to rebalance its posture and focus military and other elements of power towards the Pacific in order to provide security and safeguard the U.S. national interests in the region. Consequently, with 
budget cuts and force reductions, the U.S. Army will be compelled to change its posture in Europe. The Army will reduce force structure, redeploy forces from Europe, and rotate a battalion-size unit to the JMTC. The new posture in Europe will focus more on building partnership capacity with European and Coalition partners through security cooperation and theater engagement activities. The rotation of a regionally-aligned Army battalion through the JMTC will assure U.S. allies of our commitment and demonstrate to potential regional adversaries the U.S. military readiness, flexibility, agility, and reach. ${ }^{49}$

The redeployment of forces and rotation of units to Europe will reduce military presence in the region. In order to offset this reduction, the U.S. Army must ensure they focus on effective Coalition integration and interoperability, multinational training and partnering, and maintain European power projection platforms. These offsets will allow the U.S. Army to reduce forces while still maintaining credible capability in Europe.

\section{Endnotes}

${ }^{1}$ Barack H. Obama, Sustaining U.S. Global Leadership: Priorities for $21^{\text {st }}$ Century Defense (Washington, DC: The White House, January 2012), 2.

${ }^{2}$ Department of Defense, Defense Budget Priorities and Choices (Washington, DC: U.S. Department of Defense, January 2012), 6.

3 "Mullen: Debt is top National Security Threat," August 27, 2010, https://articles.cnn.com/2010-08-27/us/debt.security.mullen 1 pentagon-budget-national-debtmichael-mullen? s=PM:US (accessed January 8, 2013).

${ }^{4}$ Department of Defense, Defense Budget Priorities and Choices (Washington, DC: U.S. Department of Defense, January 2012), 1.

${ }^{5}$ Martin E. Dempsey, Chairman's Strategic Direction to the Joint Force (Washington, DC: Chairman of the Joint Chiefs of Staff, February 2012), 2.

${ }^{6}$ John M. McHugh and Raymond T. Odierno, Army Posture: The Nation's Force of Decisive Action, Fiscal Year 2012, Posture Statement presented to the $112^{\text {th }}$ Congress, (Washington, DC: U.S. Department of the Army, 2012), 6. 
7 John M. McHugh and Raymond T. Odierno, Army Posture: The Nation's Force of Decisive Action, Fiscal Year 2012, Posture Statement presented to the $112^{\text {th }}$ Congress, (Washington, DC: U.S. Department of the Army, 2012), 10.

${ }^{8}$ Christopher Lane, "The Almost Triumph of Offshore Balancing," January 27, 2012, http://nationalinterest.org/commentary/almost-triumph-offshore-balancing-6405 (accessed January 8, 2012).

${ }^{9}$ Christopher Lane, "The Almost Triumph of Offshore Balancing," January 27, 2012, http://nationalinterest.org/commentary/almost-triumph-offshore-balancing-6405 (accessed January 8,2012 ).

10 "Regionally Aligned Forces," December 20, 2012, linked from The United States Army Home Page at "STAND-TO!" http://www.army.mil (accessed December 20, 2012).

${ }^{11}$ Barack H. Obama, Sustaining U.S. Global Leadership: Priorities for $21^{\text {st }}$ Century Defense (Washington, DC: The White House, January 2012), 3.

12 "EUCOM Releases Command Statement on Force Posture," February 16, 2012, linked from The United States European Command Home Page at "Articles" February 16, 2012, http://www.eucom.mil/article/23125/useucom-releases-command-statement-on-force-posture (accessed December 4, 2012).

13 "EUCOM Releases Command Statement on Force Posture," February 16, 2012, linked from The United States European Command Home Page at "Articles" February 16, 2012, http://www.eucom.mil/article/23125/useucom-releases-command-statement-on-force-posture (accessed December 4, 2012).

14 "EUCOM Releases Command Statement on Force Posture," February 16, 2012, linked from The United States European Command Home Page at "Articles" February 16, 2012, http://www.eucom.mil/article/23125/useucom-releases-command-statement-on-force-posture (accessed December 4, 2012).

15 John R. Deni, The American Role in European Defense Reform (Philadelphia, PA: Foreign Policy Research Institute, Fall 2012), 532.

${ }^{16}$ John R. Deni, The American Role in European Defense Reform (Philadelphia, PA: Foreign Policy Research Institute, Fall 2012), 532.

${ }^{17}$ Zachary Selden, "The European Debt Crisis and American Security Policy," Parameters 42, no. 1 (Spring 2012): 24.

${ }^{18}$ Zachary Selden, "The European Debt Crisis and American Security Policy," Parameters 42, no. 1 (Spring 2012): 17.

${ }^{19}$ United States Joint Forces Command, The Joint Operating Environment, (Norfolk, VA: United States Joint Forces Command, 2010), 26.

${ }^{20}$ Zachary Selden, "The European Debt Crisis and American Security Policy," Parameters 42, no. 1 (Spring 2012): 24. 
${ }^{21}$ Zachary Selden, "The European Debt Crisis and American Security Policy," Parameters 42, no. 1 (Spring 2012): 24.

22 Dmitri Trenin, "The End of the EU-Russia Relationship (As You Know It)," December 28, 2012, http://www.realclearworld.com/articles/2012/12/28/the end of the eurussia relationship as you know it 100437.html (accessed January 10, 2013).

23 “2012 Failed States Index," 2012, http://www.fundforpeace.org/global/?q=fsi-grid2012 (accessed January 4, 2013).http://www.foreignpolicy.com/failed states index 2012 interactive

${ }^{24}$ Douglas J. Schaffer, "The Enduring Need for an Effective U.S. Landpower Presence in Europe," February 14, 2011, linked from The Association of the United States Army Home Page at "National Security Watch,"

http://www.ausa.org/publications/ilw/ilw pubs/nationalsecuritywatch/Documents/NSW\%20111 web.pdf (accessed January 10, 2013).

25 "Regionally Aligned Forces," December 20, 2012, linked from The United States Army Home Page at "STAND-TO!" http://www.army.mil (accessed December 20, 2012).

${ }^{26}$ U.S. Department of the Army, The United States Army Operating Concept, Training and Doctrine Pamphlet 525-3-1 (Fort Monroe, VA: Training and Doctrine Command, August 19, 2010), 8.

27 "Regionally Aligned Forces," December 20, 2012, linked from The United States Army Home Page at "STAND-TO!" http://www.army.mil (accessed December 20, 2012).

${ }^{28}$ U.S. Joint Chiefs of Staff, Joint Operations, Joint Publication 3-0 (Washington, DC: U.S. Joint Chiefs of Staff, August 11, 2011), III-28.

29 "Regionally Aligned Forces," December 20, 2012, linked from The United States Army Home Page at "STAND-TO!" http://www.army.mil (accessed December 20, 2012).

${ }^{30}$ Douglas J. Schaffer, "The Enduring Need for an Effective U.S. Landpower Presence in Europe," February 14, 2011, linked from The Association of the United States Army Home Page at "National Security Watch,"

http://www.ausa.org/publications/ilw/ilw pubs/nationalsecuritywatch/Documents/NSW\%20111 web.pdf (accessed January 10, 2013).

${ }^{31}$ United States Joint Forces Command, The Joint Operating Environment, (Norfolk, VA: United States Joint Forces Command, 2010), 22.

${ }^{32}$ United States Joint Forces Command, The Joint Operating Environment, (Norfolk, VA: United States Joint Forces Command, 2010), 23.

${ }^{33}$ Leon E. Panetta, "Building Partnership in the $21^{\text {st }}$ Century," June 28, 2012, linked from the U.S. Department of Defense Home Page at "Speeches," http://www.defense.gov/speeches/speech.aspx?speechid=1691 (accessed January 10, 2013). 
${ }^{34}$ U.S. Department of the Army, Army Doctrine Publication, ADP 1 (Washington, DC: U.S. Department of the Army, September 2012), 1-5.

${ }^{35}$ Leon E. Panetta, "Building Partnership in the $21^{\text {st }}$ Century," June 28,2012 , linked from the U.S. Department of Defense Home Page at "Speeches,"

http://www.defense.gov/speeches/speech.aspx?speechid=1691 (accessed January 10, 2013).

${ }^{36}$ U.S. Army War College, Campaign Planning Handbook, (Carlisle Barracks, PA: U.S. Army War College, 2013), 55.

${ }^{37}$ U.S. Department of the Army, Army Doctrine Publication, ADP 1 (Washington, DC: U.S. Department of the Army, September 2012), 1-2.

${ }^{38}$ U.S. Joint Chiefs of Staff, Joint Operations, Joint Publication 3-0 (Washington, DC: U.S. Joint Chiefs of Staff, August 11, 2011),V-43.

${ }^{39}$ U.S. Joint Chiefs of Staff, Joint Operational Access Concept, JOAC (Washington, DC: U.S. Joint Chiefs of Staff, January 17, 2012), i.

${ }^{40}$ U.S. Joint Chiefs of Staff, Department of Defense Dictionary of Military and Associated Terms, Joint Publication 1-02 (Washington, DC: U.S. Joint Chiefs of Staff, January 31, 2011), 143.

${ }^{41}$ U.S. Joint Chiefs of Staff, Joint Operational Access Concept, JOAC (Washington, DC: U.S. Joint Chiefs of Staff, January 17, 2012), i.

${ }^{42}$ U.S. Joint Chiefs of Staff, Joint Operational Access Concept, JOAC (Washington, DC: U.S. Joint Chiefs of Staff, January 17, 2012), i.

${ }^{43}$ Linda K. Theis, "Army Pre-Positioned Stocks (APS) Ready for Action," Army AL\&T, JulySeptember 2008, 22.

44 “Army Prepositioned Stocks: Indispensable to America's Global Force-projection Capability," December 2008, linked from the Association of the United States Army Home Page at "Torchbearer Campaign,"

http://www.ausa.org/publications/torchbearercampaign/torchbearerissuepapers/Documents/TBIP 120308.pdf (accessed January 14, 2013).

${ }^{45}$ Luke Coffey, "Keeping America Safe: Why U.S. Bases in Europe Remain Vital," Heritage Special Report no. 111 (July 11, 2012): 5, http://www.heritage.org/research/reports/2012/07/keeping-america-safe-why-us-bases-ineurope-remain-vital (accessed January 14, 2013).

${ }^{46}$ Luke Coffey, "Keeping America Safe: Why U.S. Bases in Europe Remain Vital," Heritage Special Report no. 111 (July 11, 2012): 6, http://www.heritage.org/research/reports/2012/07/keeping-america-safe-why-us-bases-ineurope-remain-vital (accessed January 14, 2013).

${ }^{47}$ Luke Coffey, "Keeping America Safe: Why U.S. Bases in Europe Remain Vital," Heritage Special Report no. 111 (July 11, 2012): 7, 
http://www.heritage.org/research/reports/2012/07/keeping-america-safe-why-us-bases-ineurope-remain-vital (accessed January 14, 2013).

${ }^{48}$ Pete Geren and George W. Casey Jr., 2009 Army Posture America's Army: The Strength of the Nation, Fiscal Year 2009, Posture Statement presented to the $111^{\text {th }}$ Congress, (Washington, DC: U.S. Department of the Army, 2009), 17.

${ }^{49}$ Stimson Defense Advisory Committee, A New US Defense Strategy for a New Era: Military Superiority, Agility, and Efficiency (Washington, DC: Stimson, November 2012), 25. 